Contents list available at IJRED website

Int. Journal of Renewable Energy Development (IJRED)

Journal homepage: http://ejournal.undip.ac.id/index.php/ijred

\title{
Utilization of Iles-Iles and Sorghum Starch for Bioethanol Production
}

\author{
Kusmiyati* and Agus Sulistiyono \\ Renewable Energy Research Centre, Department of Chemical Engineering, \\ Faculty of Engineering, Universitas Muhammadiyah Surakarta, Kartasura, INDONESIA
}

\begin{abstract}
The aims of this study were to convert the starches from iles-iles tubers (Amorphophalus campanulatus) and sorghum grains (Sorghum bicolor L) into bioethanol as an alternative energy. Both of these agricultural products contains a high content starches and they do not use as the major foods in Indonesia. To find out the maximum ethanol concentration and yield, both the raw materials were converted to ethanol on various process variables including the concentration of flour substrate solution (100-300 g/L), $\beta$-amylase enzyme concentration $(0.8-6.4 \mathrm{ml} / \mathrm{kg}$ of flour ), the concentration of dry yeast $S$. cerevisiae (2$15 \mathrm{~g}$ ), and fermentation time (72-168 hours). The results showed that at the flour substrate concentration of $250 \mathrm{~g} / \mathrm{L}$ produced the maximum ethanol contents of $100.29 \mathrm{~g} / \mathrm{L}$ and $95.11 \mathrm{~g} / \mathrm{L}$ for iles-iles and sorghum, respectively. Effect of $\beta$-amylase enzyme in the saccharification process showed that at concentration of $3.2 \mathrm{ml} / \mathrm{kg}$ the maximum reducing sugar content of $204.94 \mathrm{~g} / \mathrm{L}$ and $193.15 \mathrm{~g} / \mathrm{L}$ for iles-iles and sorghum substrate, respectively were generated therefore it was corresponding to the maximum ethanol production. The concentration effect of dry yeast $S$. cerevisiae in the fermentation stage for the iles-iles and sorghum substrate revealed that the maximum ethanol obtained at $5 \mathrm{~g}$ yeast activated in $100 \mathrm{ml}$ medium starter resulted the highest ethanol content $100.29 \mathrm{~g} / \mathrm{L} 95.11 \mathrm{~g} / \mathrm{L}$ for iles-iles and sorghum substrate, respectively. To determine the effect of fermentation time on ethanol yield from iles-iles and sorghum substrate, the fermentation process were performed at 3, 5, and 7 days. The maximum ethanol fermentation was obtained at 5 days fermentation. The ethanol yield is calculated by weight of ethanol is formed ( $\mathrm{g}$ ) divided by the weight of flour (g). Based on the experiment results, conducted, generally the highest ethanol yield of iles-iles was higher than that of sorghum flour. The highest yield $(\mathrm{g} / \mathrm{g}$ ) iles-iles and sorghum flour were 71.25 and 68.92 respectively.
\end{abstract}

Keywords: bioenergy, bioethanol, iles-iles, sorghum, S. cerevisiae

Article History: Received January 21, 2014; Received in revised form March 24, 2014; Accepted June 11, 2014; Available online

How to Cite This Article: Kusmiyati \& Sulistiyono, A. (2014) Utilization of Iles-Iles and Sorghum Starch for Bioethanol Production. Int. Journal of Renewable Energy Development, 3(2), 83-89.

http://dx.doi.org/10.14710/ijred.3.2.83-89

\section{Introduction}

World petroleum consumption has increased about $5-6 \%$ per year based on the assumption of increased in the consumption of gasoline in the world in 1990-2001 from 3.6 to 6.6 MT (Prasad et al. 2007). In Indonesia, the consumption of gasoline reached 17.5 billion L/year which 30\% comes from imported of oil producer countries (Bustaman 2008). An increasing of oil consumption causes the depletion of petroleum reserves. Therefore, alternative fuels are required to substitute petroleum. One of the alternative fuel that has been developed in the world is bioetanol.
Bioetanol is a bioenergy derived from plants, having similar properties with a petroleum fuel. Bioethanol is promising fuel as its availability in an agricultural country like Indonesia therefore it could increase revenues in the agricultural sector (Sa'nchez \& Cardon 2008). Compared with petroleum, bioethanol fuel has a colorless liquid, having a calorific value of $2 / 3$ of the gasoline, having a high octane value. For the environmental aspects, bioethanol is biodegradable liquid which produces no air pollution because it can be oxidized to be carbon dioxide and water with a little carbon monoxide (Voca et al. 2009). Mixing of ethanol with the gasoline fuel will result in more complete

\footnotetext{
* Corresponding author: (+62) 271717417

Email: kusmiyati@ums.ac.id
} 
combustion thereby reducing gas emissions (Manikandan \& Viruthagiri 2010). Mixing gasoline and bioethanol do with the composition of $10 \%$ ethanol with $90 \%$ premium called as an EXX (Zamora et al. 2010).

Bioethanol is produced from the fermentation of materials containing sugar or starch such as sugarcane, cassava, maize, sorghum and cellulose using yeast (Kargi \& Ozmihci 2006). The process for bioethanol production may use simple to high technology depends on the source of raw materials containing sugar, starch, and the most difficult is the lignocellulosic material. For lignocellulosic material, it goes through the pretreatment stage to degrade cellulose and lignin molecules. The next stage is enzymatic hydrolysis using $\alpha$-amylase (liquefaction) and $\beta$-amylase (saccharification). Then, the hydrolysed solution is fermented using microorganism (yeast), and distilled to obtain high purity of ethanol as a fuel (Verma et al. 2000).

The simplest process can be applied to the raw material of sugar and molasses (a by product of sugar mills) that is directly fermented without hydrolysis. Currently, the most ethanol plants in Indonesia use molasses as feed stock therefore the molasses dependency as feedstock and high demand of the molasses cause problems in the limitation of its availability (Suhardi 2010). Alternative raw material is required to overcome a lack of raw material supply and high prices molasses although bioethanol production from molasses feedstock is the simple process (Cazetta et al. 2007). Meanwhile, tubers and grains have been used, one of which, corn became the main raw material of bioethanol in the USA. However, the usage of corn for food make the corn usage as an energy lead to rising corn prices and the food cricis (Morris \& Brittany 2009). Cassava is also currently widely used as food so it led to drawback when the cassava used as raw material for bioethanol (Kargi and Ozmihci 2005).

Besides corn, cassava and molasses, alternative bioethanol feedstock is desirable from material that non-food crop, low cost, and easily grown on nonproductive land. In this study, As shown in Fig. 1, ilesiles tubers (Amorphophalus campanulatus) and sorghum grain (Sorghum bicolor $L$ ) were used as raw material for bioethanol. Sorghum and iles-iles are possible to be developed for bioethanol feedstock due to its advantages such as easy in the cultivation because it can live in all land types, resistant in all weather conditions. Currently, sorghum is a non-food crop and only used as animal fed (Nahar 2011). Iles-iles was chosen because it has high levels of carbohydrates and widely grown in several regions in Indonesia especially in Java (Chaeraul \& Sofnie 2006).

Various processes have been developed for ethanol production such as a Simultaneous Saccharification and Fermentation (SSF) which do not require high energy in the process. Ruiz et al. (2010) conducted a study with

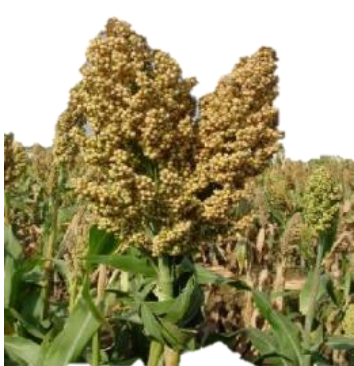

(a)

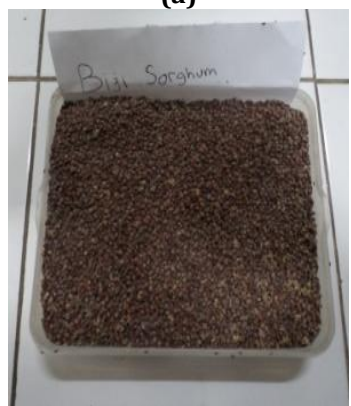

(b)

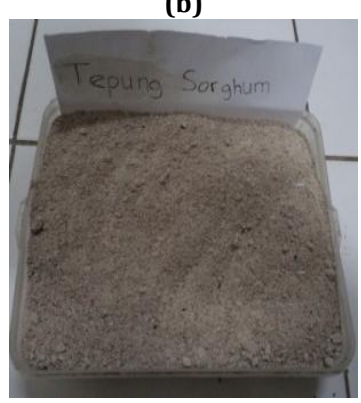

(c)

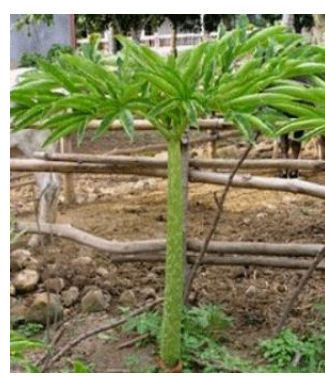

(d)

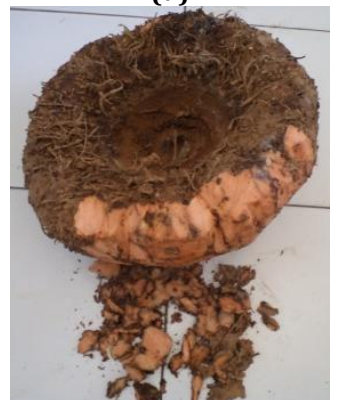

(e)

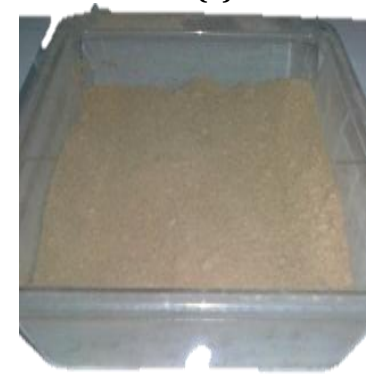

(f)
Fig. 1 sorghum crop (a), sorghum grain (b), sorghum flour (c) ; ilesiles crop (d), iles-iles tuber (e), iles-iles flour (f)

the SSF method with starchy materials by the enzyme $\alpha$ amylase (Bacillus licheriformis and Aspergillus karawachi) and glukoamylase (Aspergillus niger). The method does not require high energy, it could be done in the temperature of $30-47^{\circ} \mathrm{C}$, but the results were not optimal because only able to convert starch in low levels (Suresh et al. 1999).

Previous research using cassava tubers to produce bioethanol were consist of three-stage process, liquefaction by $\alpha$-amylase followed by saccharification by glucoamylase then fermentation using $S$. cerevisiae has been made by Zamora et al. (2010). In each stage of the process was optimized to produce maximum bioethanol production. S.cerevisiae has been widely used in previous studies for fermentation process because of its resistance in the standard conditions of pH (4.5 to 6), it's resistant to high ethanol levels, S.cerevisiae also does not require a long time in turning the glucose into ethanol, thus increasing the efficiency of making ethanol (Mamma et al. 1995).

In this study, iles-iles and sorghum were investigated as the raw materials for the production of bioethanol. For both raw materials, the bioethanol production processes were carried out in three stages, 
namely liquefaction with $\alpha$-amylase followed by saccharification with glucoamylase then fermentation using S. cerevisiae. In order to obtain the maximum ethanol from iles-iles and sorghum starch, different process variables were studied for both iles-iles and sorghum flour, various glucoamylase concentration in saccharification step, various starch: water ratio in the flour slurry and various weight of dry yeast $S$. cerevisiae in the pregrowth culture loaded on fementation.

\section{Materials and Methods}

\subsection{Raw material}

Iles-iles tubers were obtained from the farmer in Wonogiri, Central Java. Sorghum grains were obtained from local market in Wonogiri, Cental Java. Iles-iles was obtained as fresh tubers was peeled and cut into small pieces. Iles iles tubers were dried until the constant weight at moisture content of $\pm 10 \%$ (w/w). The dried iles-iles tubers were milled into flour in a size of a \pm 60 mesh. While, sorghum grain were dried and milled into flour.

\subsection{Amylotic Enzymes and Yeast}

The commercial enzymes in liquid formulations, $\alpha$ amylase (Optimax 4060 VHP, Genecor) and glucoamylase (AA Clearflo, Genecor) were used in the liquefaction and saccharification processes for the production of sugar from the iles-iles and sorghum starches as substrates. In addition, dry yeast Saccharomyces cerevisiae (Mauripan) were purchased commercially in the market in Solo Indonesia.

\subsection{Pre-growth and growth culture}

Mineral medium used for growing $S$. cerevisiae contained in grams per $100 \mathrm{ml}$; glucose, 5; peptone, 0.5 ; yeast extract, 0.5 ; potassium dihydrogen phosphate, 0.1 ; ammonium phosphate, 0.1 ; magnesium sulphate 0.1 . The mineral medium was sterilized for 20 minutes at $121^{\circ} \mathrm{C}$. Pre-growth culture of $S$. cerevisiae was prepared by loading a specified weight $(2,3,5,10,15 \mathrm{~g})$ dried yeast into $100 \mathrm{ml}$ mineral medium. The pre-growth culture was shaked in an incubator for $24 \mathrm{~h}$. Then, growth culture was prepared by inoculation $100 \mathrm{ml}$ mineral medium with $10 \mathrm{ml}$ of the pre-grown culture and it was incubated for $2 \mathrm{~h}, 150 \mathrm{rpm}$ at $30^{\circ} \mathrm{C}$. The growth culture was used as inoculate in the ethanol fermentation medium.

\subsection{Liquefaction and saccharification}

Liquefaction of starch slurry (100-300 g/L) was performed in a batch reactor stirred at $390 \mathrm{rpm}$. The liquefactions were done at constant temperature of $100^{\circ} \mathrm{C}$ in a water bath for $1 \mathrm{~h}$. The volume of starch solution was $1000 \mathrm{ml}$ employed with $\alpha$-amylase enzyme at a specific concentration per starch weigth $(1.6 \%$ $\mathrm{v} / \mathrm{w}$ ). The starch solution was adjusted to $\mathrm{pH} 6$ by addition $\mathrm{NaOH}$ solution. Then, the saccharification step was carried out by glucoamylase addition which produced glucose syrups from dextrins that obtained in the previous liquefaction step. The influence of glucoamylase enzymatic activity was determined in a different glucoamylase concentration from 0.4 to 6.4 $\mathrm{ml} / \mathrm{kg}$ starch. The saccharification was performed at constant $\mathrm{pH}(5)$, temperature $\left(60^{\circ} \mathrm{C}\right)$ and time $(4 \mathrm{~h})$. The diluted sample was centrifuged at $900 \mathrm{rpm} / \mathrm{min}$ for 15 min to separate residue and supernatant. The supernatant was analysed for sugar content.

\subsection{Fermentation}

Glucose obtained from the saccharification process was converted into ethanol by fermentation using the yeast $S$. cerevisiae. Substrate medium used for ethanol production from starch was prepared by adding the mineral medium with iles-iles or sorghum starch at various slurry concentration $(100,150,200,250$ and $300 \mathrm{~g} / \mathrm{L})$, nutrients NPK $(0.5 \% \mathrm{w} / \mathrm{v})$ and urea $(1 \% \mathrm{w} / \mathrm{v})$ were added. It was sterilized for 20 minutes at $121^{\circ} \mathrm{C}$. Fermentations were carried out by adding the substrate medium with $10 \%(\mathrm{v} / \mathrm{v})$ of the $S$. cerevisiae growth culture at constant temperatures $\left(30^{\circ} \mathrm{C}\right)$ and $\mathrm{pH} 4.5$ (adjust by using acetate buffer solution). After fermentation for $120 \mathrm{~h}$ incubation period, the fermented medium was taken for determination of ethanol and reducing sugar contents. All experiments were performed in duplicate.

\subsection{Analytical Methods}

Starch content in dry iles-iles and sorghum powder were analysed in terms of total sugar estimated after acid hydrolysis by the Nelson and Somogyi method (Breuil \& Saddler 1984). Starch content in the powder was calculated by multiplying the total reducing sugar by a factor of 0.9 . Cellulose of the powder was analyzed using the method originally described Korpos et al. (2008). The principle of this method was using two-step sulphuric acid hydrolysis.

Total sugar resulted from saccharified of iles-iles or sorghum starch and fermentation media were determined as reducing sugar. The reducing sugar contents were determined based on the dinitrosalicylic acid (DNS) method (Miller 1959). Sugar contents in the sample were analysed by taking $1.0 \mathrm{ml}$ of supernatant along with $2.0 \mathrm{ml}$ of DNS reagent in a test tube. Blank containing $1.0 \mathrm{ml}$ distilled water and $2.0 \mathrm{ml}$ of DNS was run parallel. The tubes were heated in a boiling water bath for $15 \mathrm{~min}$. After cooling the tubes at room temperature, added $8 \mathrm{ml}$ of distilled water in each and absorbance was noted at $546 \mathrm{~nm}$ using spectrophotometer. A double beam UV/VIS scanning spectrophotometer was used for measuring the absorbance. Sugar concentration was determined from 
the standard curve of glucose. Ethanol concentrations were determined by gas chromatography using GCHewlett Packard Agilent 6890N equipped with a flame ionisation detector. Helium was used as the carrier gas while hydrogen and air were used as the combustion gases.

\section{Result and Discussion}

\subsection{Raw material analysis}

Table 1 shows the results of the chemical analysis of sorghum and iles-iles powder. It can be seen that the iles-iles contains $78.94 \%$ of starch which higher than of starch content in sorghum grain (70.94\%). The presence of starch indicated that both materials could be converted into bioethanol. Another compounds found in both iles-iles and sorghum were cellulose and fermentable sugar. The cellulose and fermentable sugar of iles-iles were $1.17 \%$ and $2.92 \%$, respectively. Sorghum has higher cellulose content $(3.05 \%)$ and lower fermentable sugar $(0.57 \%)$ than that of iles-iles.

Table 1

Chemical composition of iles-iles dan sorgum (dry basis)

\begin{tabular}{ccc}
\hline \multirow{2}{*}{ Component } & \multicolumn{2}{c}{ Value (\%) } \\
\cline { 2 - 3 } & Iles-iles & Sorghum \\
\hline Moisture content & 14.66 & 16.42 \\
Cellulose & 1.17 & 3.05 \\
Reducing sugar & 2.92 & 0.57 \\
Starch & 78.94 & 70.95 \\
\hline
\end{tabular}

\subsection{Effect of $\beta$-amylase enzyme concentration in the saccharification process}

Table 2 shows the glucose and ethanol obtained from the saccharification and fermentation processes, respectively. The $\beta$-amylase enzyme concentrations in the saccharification step were varied from 0.4 to $6.4 \%$ $(\mathrm{v} / \mathrm{w})$ at the constant concentration of iles-iles and sorghum starch slurry of $250 \mathrm{~g} / \mathrm{L}$. At t the first step, liquefaction was carried at constant $\mathrm{pH}(6), \alpha$-amylase enzyme concentration $(1.6 \% \mathrm{v} / \mathrm{w})$, temperature $\left(95^{\circ} \mathrm{C}\right)$ and time $(1 \mathrm{~h})$.

Table 2

Total reducing sugar and ethanol resulted from various $\beta$-amylase concentrations in the saccharification step followed by fermentation using S.cerevisiae

\begin{tabular}{ccccc}
\hline \multirow{3}{*}{$\begin{array}{c}\text {-amylase } \\
(\mathbf{m L} / \mathbf{k g})\end{array}$} & \multicolumn{2}{c}{$\begin{array}{c}\text { Reducing sugar }(\mathrm{g} / \mathrm{L}) \\
\text { Saccharification }\end{array}$} & \multicolumn{2}{c}{$\begin{array}{c}\text { Ethanol }(\mathrm{g} / \mathrm{L}) \\
\text { Fermentation }\end{array}$} \\
\cline { 2 - 5 } & Iles-iles & Sorghum & Iles-iles & Sorghum \\
\hline 0.4 & 119.35 & 120.83 & 57.78 & 59.73 \\
0.8 & 122.45 & 151.53 & 60.35 & 75.79 \\
1.6 & 170.05 & 176.58 & 78.91 & 86.51 \\
3.2 & 204.94 & 193.15 & 100.29 & 95.11 \\
6.4 & 191.55 & 186.18 & 90.15 & 87.39 \\
\hline
\end{tabular}

The next step, saccharification process was done with keeping at a constant temperature of $60{ }^{\circ} \mathrm{C}$, $\mathrm{pH}(5)$, time ( 4 hours) with different $\beta$-amylase enzyme concentrations.

Subsequently, fermentation process was performed for 120 hours at room temperature $\left(30{ }^{\circ} \mathrm{C}\right)$ and $\mathrm{pH}$ (4.5) using $5 \mathrm{~g}$ dry yeast loaded on the preculture. The optimum reducing sugar and ethanol achieved from iles-iles substrate was $204.94 \mathrm{~g} / \mathrm{L}$ and $100.29 \mathrm{~g} / \mathrm{L}$, respectively. While reducing sugar and ethanol obtained from sorghum substrate were 193.15 $\mathrm{g} / \mathrm{L}$ and $95.11 \mathrm{~g} / \mathrm{L}$, respectively. The observed optimum ethanol from iles-iles was slightly lower than that of sorghum.

Table 2 shows that the more the addition of $\beta$ amylase in the saccharification process would increased the sugar content obtained, which in turn increased the levels of ethanol fermentation. Optimum conditions of $\beta$-amylase addition of $3.2 \mathrm{~mL} / \mathrm{kg}$ was resulted the highest reducing sugar as much as $204.94 \mathrm{~g} / \mathrm{L}$ and $193.15 \mathrm{~g} / \mathrm{L}$ for iles-iles and sorghum, respectively which corresponded to ethanol of $100.29 \mathrm{~g} / \mathrm{L}$ and 95.11 $\mathrm{g} / \mathrm{L}$ for iles-iles and sorghum, respectively The increased in $\beta$-amylase addition of $0.4 \mathrm{~mL} / \mathrm{kg}$ to 1.6 $\mathrm{mL} / \mathrm{kg}$ produced an increased the amount of reducing sugar from 119.35 to $170.05 \mathrm{~g} / \mathrm{L}$ for the iles-iles and 120.83-176.58 g/L for sorghum, which resulted an increased in ethanol content from 57.78 to $78.91 \mathrm{~g} / \mathrm{L}$ for iles-iles and from 59.73 to $86.51 \mathrm{~g} / \mathrm{L}$ for sorghum. However, the addition $\beta$-amylase of $6.4 \mathrm{~mL} / \mathrm{kg}$ resulted a lower reducing sugar than that of $3.2 \mathrm{~mL} / \mathrm{kg}$. This was consistent with research conducted by Aggarwal et al. (2001) which examined the effect on saccharification with glucoamylase enzyme at variation 10-40 U/ml. It was found that the there were an optimum saccharification percentage $(90 \%)$ at a dose of $30 \mathrm{U}$ enzyme $/ \mathrm{ml}$ for sorghum flour raw material. The ffect of glucoamylase enzyme concentration was also examined by Shewale \& Pandit (2009) which obtained an optimal concentration at $0.052 \% \mathrm{v} / \mathrm{w}$ for sorghum starch. Ruiz et al. (2011) used a variable 16.4, 37.8 and $81.6 \mathrm{U} / \mathrm{g}$ in the process of saccharification for cassava which obtained an optimum conditions for glucoamylase enzyme at $81.6 \mathrm{U} / \mathrm{g}$. This suggested that if the addition of glucoamylase enzyme was too low or too high therefore it caused saccharification process was not optimal. The results in Table 2 shows that reducing sugar and ethanol content of iles-iles were higher than that of sorghum, this was due to the content of carbohydrate in iles-iles flour material higher than sorghum.

\subsection{Effect of starch concentration in the substrate solution}

Effect of starch concentration in the sorghum and iles-iles substrate solution was performed at a different concentration of 100-300 g/L. The solution volume of 
$1000 \mathrm{ml}$ containing different weight of flour was made for both iles-iles and sorghum flour to be used as raw material in liquefaction, saccharification, and fermentation. In all experiments, the liquefaction of the substrate solution was performed at similar conditions at $\mathrm{pH}=6$ by heating at a temperature of $95^{\circ} \mathrm{C}$ for $1 \mathrm{~h}$ with addition of $\alpha$-amylase enzyme $1.6 \mathrm{~mL} / \mathrm{kg}$, followed by saccharification with similar condition: $\beta$-amylase addition of $3.2 \mathrm{~mL} / \mathrm{kg}$, temperature of $65^{\circ} \mathrm{C}$ and $\mathrm{pH} 5$ for 4 hours and similar fermentation condition at $\mathrm{pH} 4.5$, temperature of $30^{\circ} \mathrm{C}$ for 120 hours using $100 \mathrm{ml}$ of an active yeast starter containing $5 \mathrm{~g}$ of $S$. cerevisiae.

Table 3 shows the effect of starch concentration on sugar and ethanol obtained in the saccharification and fermentation process for both iles-iles and sorghum starch raw materials. Both iles-iles tubers and sorghum showed that the concentration of flour $250 \mathrm{~g} / \mathrm{L}$ produced the highest levels of biethanol which reached to $100.29 \mathrm{~g} / \mathrm{L}$ and $95.11 \mathrm{~g} / \mathrm{L}$ for iles-iles and sorghum, respectively. At a concentration of $300 \mathrm{~g} / \mathrm{L}$, glucose and ethanol obtained was lower than that of $250 \mathrm{~g} / \mathrm{L}$. At low levels of wheat starch (100-200 g/L) resulted in a reduction of sugar and ethanol for both low-iles-iles tubers and sorghum which produced ethanol from 51 to $76.75 \mathrm{~g} / \mathrm{L}$ and 58.21 to $60.13 \mathrm{~g} / \mathrm{L}$ for sorghum iles-iles, respectively.

This shows that the optimum concentration of the raw material was $250 \mathrm{~g} / \mathrm{L}$, at a concentration of 300 $\mathrm{g} / \mathrm{L}$, the solution was too viscous so that the osmotic pressure of the solution too high which resuled in a less conversion of starch into glucose and ethanol, whereas at a starch content concentration of $100-200 \mathrm{~g} / \mathrm{L}$, it produced low levels of ethanol. The fact showed that the maximum ethanol formation and sugar utilization rates were obtained at the highest sugar concentration which indicated there were no substrate or product inhibitions, but only substrate (sugar) concentration limitations within the experimental range of starch (100-250 g/L). Kargi \&Ozmihci (2006) concluded that high levels of starch solution of 200-300 g/L produced a high ethanol concentration reached to $10.5 \%(\mathrm{v} / \mathrm{v})$, whereas a low starch content $(50-150 \mathrm{~g} / \mathrm{L})$ resulted in a lower ethanol.

In addition, Shewale and Pandit (2009) stated that the most optimum concentration sorghum in the water-

\section{Table 3}

Effect of different concentration of iles-iles and sorghum substrate solution on the reducing sugar ethanol

\begin{tabular}{ccccc}
\hline $\begin{array}{c}\text { Concentration } \\
\text { of starch } \\
\text { (g/L) }\end{array}$ & \multicolumn{2}{c}{$\begin{array}{c}\text { Reducing sugar (g/L) } \\
\text { Saccharification }\end{array}$} & \multicolumn{2}{c}{$\begin{array}{c}\text { Ethanol (g/L) } \\
\text { Fermentation }\end{array}$} \\
\cline { 2 - 5 } & Iles-iles & Sorghum & Iles-iles & Sorghum \\
\hline 100 & 120.27 & 131.83 & 60.13 & 51.14 \\
150 & 125.91 & 163.41 & 58.21 & 53.41 \\
200 & 170.05 & 176.58 & 67.79 & 76.75 \\
250 & 204.94 & 193.15 & 100.29 & 95.11 \\
300 & 132.20 & 125.49 & 28.76 & 50.02 \\
\hline
\end{tabular}

was 30\% w/v. Eneojo et al. (2010) suggested that the optimum concentration of cassava flour with a water solution was $25 \% \mathrm{w} / \mathrm{v}$ which resulted ethanol yield of $5.50 \mathrm{~g} / 100 \mathrm{ml}$. Table 3 shows that the higher reducing sugar and ethanol content in iles-iles compared to sorghum was correspond to the higher concentration of starch in iles-iles than sorghum.

\subsection{Effect of yeast weight in pre-growth medium for the fermentation}

The influence of yeast concentration against ethanol levels was investigated by varying the addition of dry yeast weight (2-15g) into $100 \mathrm{ml}$ of pre-growth medium which activated in shaker for 12 hours. The pre-growth culture was inoculated in a growth culture. The growth culture was added to $1000 \mathrm{ml}$ fermentation medium at sorghum and iles-iles starch concentration of $250 \mathrm{~g} / \mathrm{L}$. For all different yeast weights, fermentation medium used was a solution of iles-iles or sorghum flour resulted from saccharification process in same condition. Fermentation was carried out for 120 hours and the same process conditions at $\mathrm{pH} 4.5$ and temperature $30^{\circ} \mathrm{C}$ which result the products shown in Table 4. The highest ethanol was obtained on the addition of $5 \mathrm{~g}$ S.cerevisiae which resulted in ethanol concentration and yield of $100.29 \mathrm{~g} / \mathrm{L}$ and 71.25, respectively for iles-iles whereas ethanol concentration and yield of $95.11 \mathrm{~g} / \mathrm{L}$ and $68.92 \mathrm{~g} / \mathrm{g}$ for sorgum, respectively.

From table 4 , it can be seen that the addition of S.cerevisiae from 5-15 g, the ethanol obtained almostsimilar. It is showed that ethanol concentration was only slightly decreased on the weight yeast between 10 and $15 \mathrm{~g}$. This result was due to the completed fermentation at 120 hours for all three variations of yeast and at the starch concentration of $250 \mathrm{~g} / \mathrm{L}$, which produced the maximum ethanol content. In contrast, at low concentration of yeast (2-3 g), the ethanol concentration was low. According to a study conducted by Ocloo \& Ayernor (2010) reported that a maximum ethanol yield $(8.3 \% \mathrm{v} / \mathrm{v})$ achieved at 120 hours using a cassava substrate fermented by dry yeast concentration of $20 \%(\mathrm{w} / \mathrm{v})$. The influence of yeast concentration at 5-15 g had affect the fermentation rate which found that at a high yeast level $5,15,20 \%(\mathrm{w} / \mathrm{v})$

Table 4

Effect of yeast weight on ethanol production by S.cerevisiae

\begin{tabular}{ccccc}
\hline \multirow{2}{*}{$\begin{array}{c}\text { Yeast weight } \\
\text { (g) }\end{array}$} & \multicolumn{2}{c}{$\begin{array}{c}\text { Reducing sugar (g/L) } \\
\text { Saccharification }\end{array}$} & \multicolumn{2}{c}{$\begin{array}{c}\text { Ethanol (g/L) } \\
\text { Fermentation }\end{array}$} \\
\cline { 2 - 5 } & Iles-iles & Sorghum & Iles-iles & Sorghum \\
\hline 2 & 58.90 & 66.51 & 58.88 & 54.65 \\
3 & 76.43 & 71.43 & 63.66 & 56.43 \\
5 & 100.29 & 95.11 & 71.25 & 68.92 \\
10 & 95.64 & 90.22 & 68.99 & 65.22 \\
15 & 94.32 & 87.51 & 67.48 & 64.52 \\
\hline
\end{tabular}


the fermentation were completed in 120,72 , and 48 hours. Abouzied \& Reddy (1986) reported the effect of yeast dry weight $(4-12 \% \mathrm{w} / \mathrm{v})$ on potato starch as fermentation substrate, the results showed that the higher concentrations of yeast lead to accelerate the time required to convert sugar into ethanol.At a concentration of yeast $4,6,8,10,12 \% \mathrm{w} / \mathrm{v}$ they required the completed fermentation time in $5 ; 4.5 ; 4 ; 3 ; 2$ days, respectively.

\subsection{Effect of fermentation time}

To determine the effect of fermentation time on the yield of ethanol from iles-iles tubers and sorghum grain, it was performed at 3, 4, and 5 days. Fermentation medium was resulted from saccharification of starch solution with a concentration of $250 \mathrm{~g} / \mathrm{L}$. The fermentation medium was added with $100 \mathrm{ml}$ activated growth culture S.cerevisiae containing $5 \mathrm{~g}$ of dry yeast and mineral nutrients. Fermentation was carried out at $\mathrm{pH} 4.5$ and room temperature 27 $30^{\circ} \mathrm{C}$. Ethanol concentration from iles-iles and sorghum flour with variation fermentation time of 72,96 , and 120 hours can be seen in Fig. 2. As shown in Fig. 2, ilesiles and sorghum flour were obtained at $96 \mathrm{~h}$ which produced maximum ethanol of $100.29 \mathrm{~g} / \mathrm{L}$ and 95.11 $\mathrm{g} / \mathrm{L}$ for iles-iles and sorghum, respectively, and correspond to maksimum yield of $78.02 \mathrm{~g} / \mathrm{g}$ and 88.10 $\mathrm{g} / \mathrm{g}$ for iles-iles and sorghum, respectively. Yield was calculated by weight of ethanol (g) was divided by the weight of flour (g). The results obtained at fermentation time $72 \mathrm{~h}$ were $89.20 \mathrm{~g} / \mathrm{L}$ and $85.16 \mathrm{~g} / \mathrm{L}$ for the iles-iles and sorghum, respectively. The reduction of ethanol was also observed for fermentation time at 120 hours.

A study conducted by Ocloo and Ayernor (2010) suggested that the optimum time for fermentation using the S.cerevisiae achieved at 5 days (120 hours). In previous research Ocloo \& Ayernor (2010) was using a cassava substrate with S.cerevisiae concentration of 5 gram and fermentation time of 120 hours ( 5 days) and found the maximum ethanol of $8.30 \% \mathrm{v} / \mathrm{v}$. The result obtained by Verma et al. (2000) showed that the maximum fermentation time was 120 hours, which obtained the highest ethanol of $21.6 \% \mathrm{~g} / \mathrm{l}$ and fermentation efficiency of $93 \%$ using SSF method (simultan saccharification and fermentation). Voca et al. (2009) got the maximum ethanol yield $57.38 \mathrm{~g} / \mathrm{L}$ after fermentation 16 hours using corn flour feedstock with $S$. cerevisiae yeast at a concentration of $6 \mathrm{~g} / \mathrm{L}$.

The shorther fermentation time occured when the treatment proces prior to fermentation process was carried out which consisted of three steps, first drying of $130{ }^{\circ} \mathrm{C}$ on the corn meal, followed by evaporation in the autoclave at a temperature of $121^{\circ} \mathrm{C}$, pressure of 1.5 bar, for 20 minutes and the hydrolysis with $\alpha$-amylase and $\beta$-amylase. Moreover, Mahanty et al. (2009) suggested that it take 72 hours to obtain the maximum ethanol (195 g/kg raw material) using mahula plant as

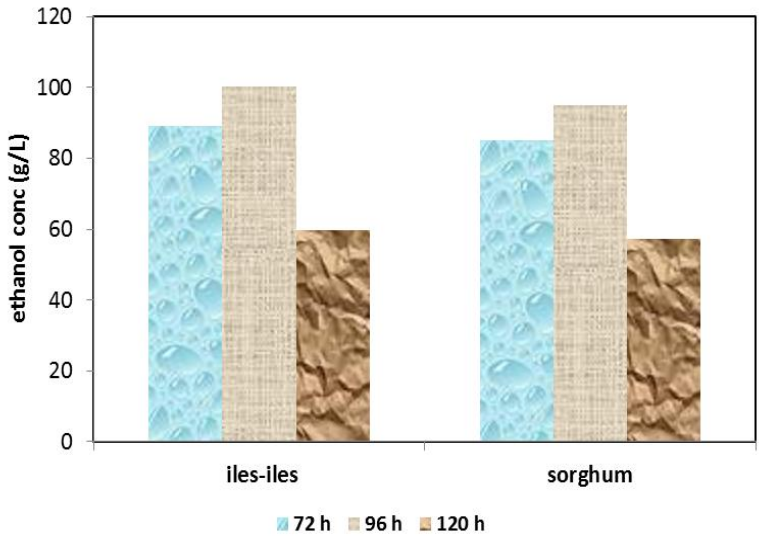

Fig. 2 Effect of fermentation time on ethanol concentration

a raw material. The results showed an increased ethanol until 72 hours that caused by the increased cell microorganisms from $3 \times 108 \mathrm{CFU} / \mathrm{g}$ substrate $(0 \mathrm{hr})$ to $8.5 \times 109 \mathrm{CFU} / \mathrm{g}$ substrate (72 hours). After 72 hours, the ethanol concentration decreased due to the reduced substrate and the presence of yeast inhibitor at high ethanol levels.

\section{Conclusion}

The results of this study showed that iles-iles and sorghum starch were good source for bioconversion into ethanol fuel. The processes of bioethanol production from the starch were carried out in three steps: liquefaction, saccharification, and fermentation. The parameter had affected on the reducing sugar and ethanol produced were investigated including the starch concentration of substrate slurry (100-300 g/L), $\beta$-amylase enzyme concentration $(0.8-6.4 \mathrm{ml} / \mathrm{kg}$ of flour ), the weight of dry yeast $S$. cerevisiae (2-15 g), and fermentation time (72-120 hours).

The optimum concentrations of sorghum and ilesiles slurry were observed to be $250 \mathrm{~g} / \mathrm{L}$, at which produced the maximum ethanol contents $100.29 \mathrm{~g} / \mathrm{L}$ and $95.11 \mathrm{~g} / \mathrm{L}$ for iles-iles and sorghum, respectively. During the saccharification using $\beta$-amylase the optimum concentration was found to be $3.2 \mathrm{ml} / \mathrm{kg}$ of flour at which maximum reducing sugar content were observed at 204,94 g/L and 193,15 g/L for iles-iles and sorghum raw materials, respectively therefore resulted the highest ethanol as well. The effect of yeast concentration showed that a weight of 5 dry $S$. cerevisiae was found to be the optimal for ethanol production where the highest final ethanol yield was achieved from both iles-iles and sorghum starch.

Fermentation time $(72,96,120$, hours) also had affect on the ethanol produced, the longer the fermentation (0-120 hours) the ethanol content increased, but further increase time higher than 120 decreased ethanol yield. Iles-iles starch produced 
slightly higher ethanol concentration than that of sorghum flour therefore it has the potential for supplement existing bioethanol feedstocks, which could be of significance to the rural economy of Indonesia.

\section{Acknowledgements}

The authors gratefully acknowledge to Directorate of Higher Education of Indonesia for the financial Research Grants (Contract no: 007/006.2/PP/SP/2012).

\section{References}

Aggarwal, N.K., Nigam, P., Singh, D. \& Yadav, B.S. (2001) Process Optimization For The Production Of Sugar For The Bioethanol Industry From Sorghum A Non-Conventional Source Of Starch, World Journal of Microbiology and Biotechnology, 17, 411-415.

Bustaman \& Sjahrul (2008) Strategi Pengembangan Bio-Etanol Berbasis Sagu di Maluku. Perspektif, 7(2), 65-79.

Cazetta, M.L., Celligoi, M.A.P.C., Buzato, J.B. \& Scarmino, I.S. (2007) Fermentation Of Malasses By Zymomonas mobilis Schott)) Effects Of Temperature and Sugar Concentration on Etanol Production. Bioresource Technology, 98, 2824-2828.

Chairul \& Sofnie, M. 2006. Isolasi Glukomanan dari Dua Jenis Araceae Talas (Colocasia Esesculenta (L.) Schott) dan Iles-iles (Amorphophalus Campanulatus Blumei). Berita Biologi. 8.

Eneojo, A. S., Aliyu, S. \& Bukbuk, D.N. (2010) Potential of Wild Strain Saccharomyces cerevisiae in Ethanol Production. AmericanEurasian Jurnal of Scientific Research, 5(3), 187-191.

Kargi, F. \& Ozmihcl, S. (2006) Utilization of Cheese Whey Powder (CWP) for Etanol Fermentations: Effects of Operating Parameters. Enzyme and Microbial Technology, 38, 711-718.

Mamma, D., Christakopoulos, P., Koullas, D, Kekos, D., Macris, B. J. \& Kouki, E. (1995) An Alternative Approach to the Bioconversion of Sweet Sorghum Carbohydrates to Ethanol. Biomass and Bioenergy, 8 (2), 99-103.

Manikandan, K \& Viruthagiri, T (2010) Kinetic and Optimization studies on Ethanol Production from Corn Flour. International Jurnal of Chemical and Biological Engineering, 5, 32-38.
Mohanty, S.K., Behera, S., Swain, M.R. \& Ray, R.C. (2009) Bioethanol production from mahula (Madhuca latifolia L.) flowers by solidstate fermentation. Applied Energy, 86, 640-644.

Morris, \& Brittany, D. (2009) Economic Feasibity of Etanol Production from Sweet Sorgum Juice in Texas. Southern Agricultural Economics Association Annual Meetings, Atlanta, Georgia.

Nahar, K. (2011) Sweet Sorgum: an Alternative Feedstock for Bioetanol. Iranica Journal of Energy \& Environment, 2 (1), 58-61.

Ocloo, F. C. K. \& Ayernor, G. S. (2010). Production of Alcohol from Cassava Flour Hydrolysate. Journal of Brewing and Destilling, 1(2), 15-21.

Prasad, S., Singh, A. \& Joshi, H.C. (2007) Etanol As An Alternative Fuel From Agricultural, Industrial And Urban Residues. Resources, Conservation And Recycling, 50, 1-39.

Ruiz, M.I., Sanchez, C.I, Torrresa R.G. \& Molina, D.R. (2011) Enzymatic Hydrolysis of Cassava Starch for Production of Bioetanol with a Colombian Wild Yeast Strain. Journal of the Brazilian Chemical Society, 22(12), 2337-2343.

Sa'nchez, O. \& Cardona, C.A. (2008) Trends in Biotechnological Production of Fuel Etanol from Different Feedstocks. Bioresource Technology, 99, 5270-5295.

Shewale, S.D. \& Pandit, A.B. (2009) Enzymatic Production of Glucose From Different Qualities of Grain Sorgum and Application of Ultrasound to Enhance The Yield. Carbohydrate Research, 344, 5260.

Suhardi. 2010. Harga Tetes Tebu Melambung Tinggi. Solopos 13 Februari 2010. http://www.solopos.com/2010/sukoharjo/hargatetes-tebu-melambung-tinggi-14650, accessed May 31, 2011 at $13.30 \mathrm{pm}$.

Suresh, K., Sree, N.K., \& Rae, L.V. (1999) Utilization of Damaged Sorgum and Rice Grain for Etanol Production by Simultaneous Saccharification and Fermentation. Biosource Technology, 68, 301304.

Verma, G., Nigam, P., Singh, D. \& Chaudhary, C. (2000) Bioconversion of Starch to Etanol in a Single-Step Process by Coculture of Amylolytic Yeast and Saccharomyces cerevisiae 21. Bioresource Technology, 72, 261-266.

Voca, N., Varga, B., Kricka, T., Curic,D., Jurisic, V. \& Vatin, A. (2009) Progress in Ethanol Production from Corn Kernel by Applying Cooking Pre-treatment. Bioresource Technology, 100, 2712-2718.

Zamora, L.L., Calderón, J.A.G., Vázquez, E.T., \& Reynoso, E.B. (2010) Optimization of Etanol Production Process from Cassava Starch by Surface Response. Journal of the Mexican Chemical Society, 54 (4), 198-203. 